\title{
DO STAKEHOLDERS MATTER IN STRATEGIC DECISION MAKING OF A SPORTS ORGANIZATION?
}

\author{
Stakeholders são importantes na tomada de decisão estratégica em uma \\ organização desportiva? \\ ¿Los stakeholders son importantes en la toma de decisión estratégica en una \\ organización deportiva?
}

\begin{abstract}
This study aims to identify and prioritize the stakeholders involved in making decisions in a sports organization. A multiple linear regression analysis was used to assess the influence of the attributes of power, legitimacy and urgency on the salience of the various stakeholders. The results showed a convergence of external and internal decision makers' perceptions, concerning the three main stakeholder groups: top management, sponsors and member association. Pearson correlations identified four types of stakeholder: definitive, dangerous, demanding and non-stakeholders. A generalized differentiation was also found in stakeholder classification, regarding evaluation of attributes, between external and internal decision makers. In addition, the study suggests the success of organizations' management will depend on correct identification of stakeholders and consequent assessment of their relevance, in order to highlight who should get priority, and how, in strategic decision making.

KEYWORDS | Stakeholder analysis, decision making, strategy, sport clubs, football
\end{abstract}

\section{RESUMO}

Este trabalho visa identificar e priorizar os stakeholders envolvidos na tomada de decisão de uma organização desportiva. Foi utilizada uma análise de regressão linear múltipla para avaliar a influência dos atributos poder, legitimidade e urgência na saliência dos diversos stakeholders. Os resultados evidenciaram uma convergência das perceções dos decisores externos e internos, quanto aos três principais grupos de stakeholders: gestão de topo, patrocinadores e massa associativa. Identificaram-se quatro tipos de stakeholders: definitivos, perigosos, exigentes e não-stakeholders. Verificou-se ainda uma diferenciação generalizada na classificação dos stakeholders, relativamente à valorização dos atributos, entre os decisores externos e internos. O estudo sugere que o êxito da gestão das organizações dependerá da identificação correta dos stakeholders e consequente avaliação da relevância destes, de forma a salientar a quem e como deve ser dada prioridade na tomada de decisão estratégica.

\section{MIRAGAIA}

miragaia@ubi.pt

PhD in Sport Science at

Departamento de Ciências do

Desporto, Universidade da Beira

Interior - Covilhã, Portugal

\section{JOÃO FERREIRA}

jjmf@ubi.pt

PhD in Management, Departamento

de Gestão e Economia, Universidade da Beira Interior - Covilhã, Portugal

\section{ANDRÉ CARREIRA}

andrecarreira87@hotmail.com

MSc in Sport Science, Departamento de Gestão e Economia, Universidade da Beira Interior - Covilhã, Portugal

\section{RESUMEN}

Este trabajo busca identificar y priorizar a los stakeholders comprendidos en la toma de decisión de una organización deportiva. Se utilizó un análisis de regresión linear múltiple para evaluar la influencia de atributos, poder, legitimidad y urgencia en la visión de diversos stakeholders. Los resultados evidencian una convergencia de las percepciones de los decisores externos e internos, con los tres principales grupos de stakeholders: gestión de tope, patrocinadores y masa asociativa. Se identificaron cuatro tipos de stakeholders: definitivos, peligrosos, exigentes y no-stakeholders. Se verificó también una diferencia generalizada en la clasificación de los stakeholders, relativamente a la valorización de los atributos, entre los decisores externos e internos. El estudio sugiere que el éxito de la gestión de las organizaciones dependerá de la correcta identificación de los stakeholders y su consecuente evaluación de relevancia de estos, como forma de reafirmar a quién y cómo debe ser dada la prioridad en la toma de una decisión estratégica.

PALABRAS-CLAVE I Stakeholders, toma de decisión, estrategia, clubes, fútbol. 


\section{INTRODUCTION}

Stakeholder theory emerged as another contribution towards a better understanding of organizational management through focusing on the groups or individuals who either affect or are affected by the organization's actions (Freeman, 1984). Thus, an organization's social performance may be more effectively analyzed and assessed through its relations with its stakeholders (Mainardes, Alves \& Raposo, 2011).

Stakeholder theory has often been applied to the industrial sector and, furthermore, when applied to the sports context, some similarities are found with those industries. In particular, senior sports management is under ever-increasing scrutiny and this has inevitably led to management practice related questions (Ferkins \& Shilbury, 2010).

Due to the all-encompassing professionalization of various sports in the last two decades, particularly football, we find sport itself is now perceived as an industry (Zagnoli \& Radicchi, 2010; Anagnostopoulos, 2011). This factor drives the need for sports managers to be ever better informed and aware of developments ongoing in the respective sport's political, social and economic environment, as well as in the stakeholders involved as is indeed already the case in other industries (Eesley \& Lenox, 2006; Breitbarth \& Harris, 2008). To improve performance, football clubs increasingly need to adopt good management practices within the framework of which dialogue with stakeholders proves essential (Michie \& Oughton, 2005; Holt, 2007; Ferkins \& Shilbury, 2010). Therefore, organizations must identify and prioritize stakeholders in order to improve the efficiency and outcomes of their decision-making processes.

In the studies identified in the literature, the stakeholder attributes approach (Mitchell, Agle \& Wood, 1997) has been little applied to the football world for analysis of strategic decision making. Therefore, given the gap identified, this study aims to identify and analyze external and internal stakeholders perceptions on strategic decision making and to evaluate what impact the relationships among the attributes of power, legitimacy and urgency have on the salience of these stakeholders.

\section{LITERATURE REVIEW}

Stakeholder theory enables managers to move on from organization-based approaches in which stakeholders are seen as dependent bodies and managed exclusively for the organization's own benefit, to an approach based on the relationship networks and concepts existing in any organization (Nguyen \& Menzies, 2010).
Freeman and Reed (1983), present two distinct definitions for stakeholders, the first referring to any group or individual that affects or is affected by the consequences of an organization striving to attain its objectives. The second refers to groups, or individuals, creating dependence in a company and becoming essential for its survival.

Freeman (1984) opts for the first definition of stakeholders and lists employees, customers, suppliers, shareholders, banks, environmentalists, the government among the groups that are able to harm or help the organization. Furthermore, Donaldson and Preston (1995) define stakeholders as all the people and/or group(s) with legitimate interests, participating in the organization, and attributed explicit or implicit contracts in order to obtain benefits and without any other specific interest. In another definition of stakeholders proposed by Clarkson (1995), these are individuals or groups with ownership, rights or interests in an organization and in its past, present or future activities.

To satisfy the organization's most important stakeholders, managers must first of all identify those holding most influence (Mitchell et al., 1997; Driscoll \& Starik, 2004; Aaltonen, Jaakko \& Tuomas, 2008). One of the great failures of organizations stems from a lack of strategy for identifying and dealing with present and future stakeholders (Freeman, 1984). Hence, organizations simply cannot ignore their existence and must interact with them thereby enabling managers to relate to stakeholders and to monitor the ongoing transactions and exchanges (Freeman, 1984; Parent \& Séguin, 2007; Aaltonen et al., 2008).

As regards the identification and the subsequent relationship between stakeholders and the organization, Friedman, Parent \& Mason (2004) suggest four aspects for identifying stakeholders: a) a direct or indirect connection between stakeholders and the organization; b) measurable interests; c) perceived as a legitimate and integral part of the organization; and d) stakeholders may undertake different functions.

According to Friedman et al. (2004), not only do stakeholders need to identify their expectations and needs, but also evaluate the potential impact of environmental trends that may affect them.

From this literature review of stakeholder classification, the following main approaches stand out: a) descriptive, instrumental and normative (Donaldson \& Preston, 1995); b) internal and external (Freeman, 1984; Olander, 2007); and c) power, legitimacy and urgency attributes (normative approach) and the salience as a feature (descriptive approach) (Mitchell et al., 1997).

The descriptive approach refers to the organization's nature and purpose, the respective ways of thinking and managerial perceptions of stakeholders. The instrumental approach assesses stakeholder impacts on organizational performance. As 
regards the normative approach, this deals with interpreting and rendering the organization's operating functions based on moral and philosophical principles.

According to Freeman (1984) and Olander (2007), the internal stakeholders are responsible for the implementation of the organizational project and the external stakeholders are affected by the project.

In an attempt to complement stakeholder identification and classification, Mitchell, et al. (1997) propose an approach based on three attributes: power, legitimacy, urgency, and salience as a feature. This approach is subsequently adopted by several studies (Driscoll \& Starik, 2004; Eesley \& Lenox, 2006; Parent \& Deephouse, 2007; Aaltonen et al., 2008; Mainardes et al., 2012).

Power is defined as the stakeholder's capacity to influence the organization, with Harrison, Bosse \& Phillips (2010) referring to the concept as the first criterion to prioritize when taking into account the factors influencing the organization's decisions and distribution of value. Legitimacy is defined by Mitchell et al. (1997) as the generalized perception that the actions of any given organization are convenient, suitable or appropriate according to social definitions, norms, values and beliefs. According to Mitchell et al. (1997), urgency is the degree to which stakeholders demand immediate attention and which endows them with greater dynamism. The foundations for urgency are associated with time sensitivity, i.e., the extent to which managers delay in attending to stakeholder requests and their respective level of pertinence. Finally, salience was defined by Mitchell et al. (1997) as the degree to which managers award priority to stakeholder requests resulting from the combination and accumulation of the previous attributes. Stakeholders should be attributed priority according to their level of salience in accordance with the following (Mitchell et al., 1997; Friedman et al., 2004): a) low, when stakeholders have only one attribute; b) moderate, when displaying two attributes; c) high, when attaining all three attributes. In this latter case, managers should prioritize these stakeholder requests. Stakeholders, therefore, may be prioritized by different types: Definitive, Dominant, Dependent, Dangerous, Dormant, Discretionary, Demanding, and Non-Stakeholders (Mitchell et al., 1997).

Stakeholder theory research, particularly as applied to the sports industry, remains in its infancy (Russo \& Vito, 2011). Nevertheless, there already are some published research findings in this field, especially on swimming (Parent \& Séguin, 2007; Breitbarth \& Harris, 2008; Ferkins \& Shilbury, 2010), on sporting events (Sotiriadou, 2009; Parent, Rouillard \& Leopkey, 2011; Sallent, Palau \& Guia, 2011; Xue \& Mason, 2011) and on football (Michie \& Oughton, 2005; Stevens \& Watkins-Mathys,
2006; Holt, 2007; Anagnostopoulos, 2011; Peachey \& Bruening, 2011; Walters, 2011).

Sotiriadou (2009) approaches the subject of stakeholders in studying their capacity to influence the financial performance of sports organizations. Meanwhile, Holt (2007) applies stakeholder theory to find out to what extent the existence of an internal and external network of stakeholders actually influences football focused management structures.

However, Breitbarth and Harris (2008) argue that the application of this theory remains something new to professional football managers, in terms of explicit knowledge on stakeholders (often contractual), the degree of transparency incorporated into business practices, or even interactions with groups formally considered as beyond the game's scope. In addition, in a study applied to American university football, Bravo (2004) tried to prioritize manager choices in relation to stakeholders existing in the state education system. Taking a similar line, Anagnostopoulos (2011) sought to identify to whom Greek football club managers should pay most attention.

Given this context, we may identify two gaps in the literature on applying stakeholder theory to the context of sports organizations: a) in the sphere of football, no study has applied the Mitchell et al. (1997) attributes to studying strategic decision making (i.e., budgetary, goal-setting, players' acquisition, managerial structure); and b) the studies focused in sport management context, do not include simultaneously the perceptions of internal and external stakeholders.

In order to overcome the aforementioned shortcomings in the literature, this research aims first to contribute to plugging these gaps in the literature and also to empirically test in what ways stakeholder theory, particularly the stakeholder attributes approach, serves as a tool in support of strategic decision making by sport organizations.

\section{Conceptual Model and Hypotheses}

The proposed model is based on the attributes approach by Mitchell et al. (1997) and aims to relate internal and external decision maker perceptions of the individual and cumulative attributes to the salience of football club stakeholders (Figure 1).

Experts in sports management have displayed an increasing interest in the impact of stakeholders on the management of sports organizations (Esteve et al., 2011; Russo \& Vito, 2011). A major challenge facing management teams stems from the degree of confidence they convey to stakeholders. Management practices must integrate and take stakeholder expectations into account, and, whenever feasible, place them at the core of decision making (McDonald \& Sherry, 2010). Thiel and Mayer (2009) state that club 
management is not limited to the president and to directors, because by their very own individual nature, each member (members and/or fans) can and should take an active role in decision-making processes and in defining club objectives. Stakeholder power results from the ability to mobilize its own political and social forces, as well as the capacity to draw down income from the organization (Olander, 2007). Sotiriadou (2009) argues that some stakeholders gain their greatest power in terms of the control they hold over the resources needed by the club.

Hypothesis 1a: In the perception of external decision makers, the stakeholder Power attribute is positively related to the stakeholders' Salience.

Hypothesis $1 \mathrm{~b}$ : In the perception of internal decision makers, the stakeholder Power attribute is positively related to the stakeholders' Salience.

Zagnoli and Radicchi (2010) identify various different strategic positioning of football club stakeholders, supported by a trend to cooperate and/or represent potential threats to the organization. They point out that at one extreme there are the club partners, with high cooperative potential and influencing the strategic choices, while at the other extreme there are members and supporters posing a high level of threat to the club and who aggressively call its mission into question. Correspondingly, legitimacy may be achieved by adopting the social norms and behaviors accepted by other stakeholders (Shropshire \& Hillman, 2007).

Hypothesis 2a: In the perception of external decision makers, the stakeholder Legitimacy attribute is positively related to the stakeholders' Salience.

Hypothesis $2 \mathrm{~b}$ : In the perception of internal decision makers, the stakeholder Legitimacy attribute is positively related to the stakeholders' Salience.

Urgency should be the criteria for determining the level of priority a stakeholder deserves, i.e., reflecting its respective degree of importance to the organization (Neville, Bell \& Whitwell, 2011).

Hypothesis 3a: In the perception of external decision makers, the stakeholder Urgency attribute is positively related to the stakeholders' Salience.

Hypothesis $3 \mathrm{~b}$ : In the perception of internal decision makers, the stakeholder Urgency attribute is positively related to the stakeholders' Salience.

Parent and Deephouse (2007) examine the identification of stakeholders and the degree of priority awarded by managers through comparing two organizational committees for two large sporting events. They verify a positive relationship between the number of stakeholder attributes and their relevance before concluding that the attribute of power followed by urgency and legitimacy have greatest relevance for decision making.

Hypothesis 4a: In the perception of external decision makers, the cumulative attributes of Power, Legitimacy and Urgency positively relate to the stakeholders' Salience.

Hypothesis $4 \mathrm{~b}$ : In the perception of internal decision makers, the cumulative attributes of Power, Legitimacy and Urgency positively relate to the stakeholders' Salience.

This salience reflects the priority attributed by managers to ensuring good organizational management involving leveraging the operating input of stakeholders in order to improve this performance (Samaras, 2010; Neville et al., 2011).

\section{Figure 1. Conceptual model}

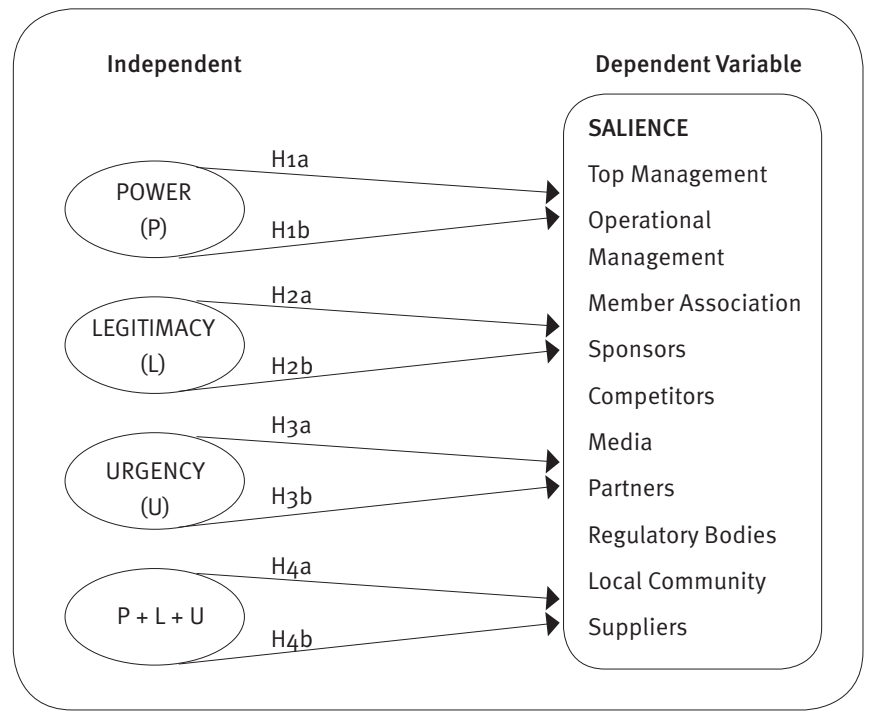

\section{METHODOLOGY}

The unit of analysis in this case study focuses on a Portuguese football club, Centro Desportivo Fátima, currently playing in the Portuguese Second Division, the Orangina League. It should be noted that this club was once also connected to a broader range of sporting activities, including track and field, roller-hockey, ice-skating and ballroom dancing. At present, it focuses on its main football team, and on youth football. Male and female fivea-side football also takes place and resulting in a total of around 300 sports participants at the club. 


\section{Method}

First, and in accordance with the findings of our literature review, the club's internal and external stakeholders were identified and one list was done. To verify if the recommendations mentioned the literature was adjusted to this case study, the directors of the club ( 10 members of the Board of Directors, 2 of the General Assembly, and 2 of the Supervisory Council) were interviewed to select what they considered as internal and external stakeholders. This process led to a total of 48 stakeholders identified and classified into 10 groups: Top management; operations management (i.e., players, staff, coaches); member association; sponsors; competitors; media; partners; regulatory bodies; local community; and suppliers.

Afterwards, we draw a questionnaire organized into three different sections and administered to a two stakeholder groups: internal and external. At the first section we obtained data relative to the sample (age, gender, stakeholder type, type of contract with the club: formal or volunteer).

In order to test the conceptual model the second section of the questionnaire, asked to rank the 48 stakeholders according to the power (P), legitimacy (L), urgency $(\mathrm{U})$ and salience $(\mathrm{S})$, which had in the strategic decision-making process of the club. As proposed by Agle, Mitchell \& Sonnenfeld (1999) a seven-point Likert scale was applied (1 for completely agree, to 7 for completely disagree).

Finally, in the third section of the questionnaire, an open question was defined in order to know what stakeholders consider more important for strategic decision making and why.

As regards internal decision makers, of a total of 20 members, 13 questionnaires were answered by: General Assembly (1); Supervisory Council (1); Board of Directors (5); Senior team sports directors (3); Youth coordinators (2); and Senior team manager (1). In the case of external decision makers (paid-up associate members), the club has 300 members. We considered only members who participating in a regular way at General Assembly meetings (out of a total of 30 , were included $26 \mathrm{mem}$ bers). The total sample was $82 \%$ male and $18 \%$ female, with an average respondent age of 42.62 years. Furthermore, of the total number of respondents, $90 \%$ are volunteers with only $10 \%$ holding a formal/contractual relationship with the club.

To test our hypotheses, we deployed multiple regression analysis and prioritized and classified stakeholder groups, with the Pearson test applied to analyze correlations. The software was the SPSS program version 17.0 (SPSS Inc., Chicago, Illinois, USA).

\section{DISCUSSION OF RESULTS}

\section{Salience of stakeholders in strategic decision making}

The stakeholder attribute scale reliability returns Alpha values >0.93 (Table 1), which confirms their robustness (Field, 2005).

\section{TABLE 1. Stakeholder attribute reliability}

\begin{tabular}{|c|c|c|c|c|}
\hline Scale & $P$ & L & $\mathrm{U}$ & $S$ \\
\hline $\begin{array}{l}\text { 1- The requests of this stakeholder in particular are seen by the organization as legitimate. } \\
\text { 2- The organization understands that this stakeholder's requests are not suitable. } \\
\text { 3- The requests of this stakeholder are considered as legitimate in the eyes of the club. } \\
\text { a } 2\end{array}$ & & $\begin{array}{l}0.95 \\
0.96 \\
0.96 \\
0.95\end{array}$ & & \\
\hline $\begin{array}{l}\text { 1- This stakeholder presents urgency in his relationship with the club. } \\
\text { 2- This stakeholder actively seeks to gain attention for requests submitted. } \\
\text { 3- This stakeholder communicates his requests to the club with urgency. } \\
\text { a3 }\end{array}$ & & & $\begin{array}{l}0.96 \\
0.97 \\
0.96 \\
0.97\end{array}$ & \\
\hline
\end{tabular}

$\mathrm{P}=$ Power; L=Legitimacy; U=Urgency; $\mathrm{S}=$ Salience. 
In validating the hypotheses corresponding to external decision makers (Hyp. 1a; 2a; 3a; and 4a), we observe that the attributes of power, legitimacy and urgency are related to the salience (Table 2). We also found that the attribute of power has a positive relationship only with salience of operations management $(\beta=0.58)$; regulatory bodies $(\beta=0.55)$; and suppliers $(\beta=0.65)$ presenting adjusted $R^{2}$ coefficient values of $0.25 ; 0.03$ and 0.37 , respectively. This means that power is the attribute best explaining the salience of these stakeholder groups. Therefore, Hyp. $1 \mathrm{a}$ is partially confirmed whilst Hyp. $2 \mathrm{a}$ is not confirmed. Urgency (Hyp. 3a) correlates positively only with the salience of partners $(\beta=0.42)$, presenting an adjusted $R^{2}$ coefficient value of 0.3 , with urgency representing the attribute that best explains partner salience. This hypothesis is thereby partially confirmed. As for Hyp. $4 \mathrm{a}$, this is almost totally confirmed as the cumulative attributes correlate with the salience of all stakeholder groups, except for top management and sponsors.
Regarding validation of the hypotheses corresponding to internal decision makers (Hyp. $1 \mathrm{~b} ; 2 \mathrm{~b} ; 3 \mathrm{~b}$; and $4 \mathrm{~b}$ ), we may report that the power, legitimacy and urgency attributes are related to that of salience (Table 2). The results also show that the power attribute correlates only with the salience of the local community ( $\beta=0.64 ; R^{2}$ adjusted $=0.79$ ), with power being the factor best explaining the salience of this stakeholder group. This, therefore, partially confirms Hyp. 1b. The legitimacy attribute does not correlate with the other salience-related attributes, and thus Hyp. $2 b$ is not confirmed. As for Hyp. $3 b$, we partially confirm this as urgency does correlate with the salience of the following stakeholder groups: operations management, member associations, sponsors, partners and regulatory bodies, with urgency being the attribute best explaining their salience. Finally, regarding Hyp. $4 \mathrm{~b}$, the results almost totally confirmed this, as a correlation was reported between the cumulative attributes and salience, except for the top management, sponsors and the media stakeholder groups

\section{TABLE 2. Regression analysis of external and internal decision makers ${ }^{a}$}

\begin{tabular}{|c|c|c|c|c|c|c|c|c|c|c|c|}
\hline & Variables & \begin{tabular}{|c|} 
Top \\
Management \\
Salience \\
\end{tabular} & \begin{tabular}{|c|} 
Operations \\
Management \\
Salience \\
\end{tabular} & \begin{tabular}{|c|} 
Member \\
Association \\
Salience \\
\end{tabular} & $\begin{array}{l}\text { Sponsors } \\
\text { Salience }\end{array}$ & $\begin{array}{c}\text { Competitors } \\
\text { Salience }\end{array}$ & $\begin{array}{c}\text { The } \\
\text { Media } \\
\text { Salience }\end{array}$ & $\begin{array}{l}\text { Partners } \\
\text { Salience }\end{array}$ & \begin{tabular}{|c|} 
Regulatory \\
Bodies \\
Salience \\
\end{tabular} & \begin{tabular}{|c|} 
Local \\
Community \\
Salience \\
\end{tabular} & $\begin{array}{l}\text { Suppliers } \\
\text { Salience }\end{array}$ \\
\hline \multirow{7}{*}{ 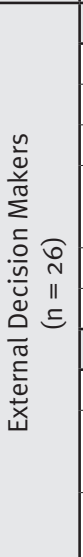 } & \multicolumn{11}{|c|}{ Individual Attributes } \\
\hline & Legitimacy & 0.16 & 0.14 & 0.05 & 0.08 & 0.06 & 0.30 & 0.02 & 0.01 & 0.33 & 0.06 \\
\hline & Urgency & -0.45 & -0.14 & 0.06 & -0.08 & 0.41 & 0.28 & $0.42^{\star}$ & 0.04 & -0.13 & -0.01 \\
\hline & $\mathrm{F}$ & 1.59 & 3.84 & 2.77 & 0.12 & 2.45 & 2.78 & 4.50 & 3.54 & 3.10 & 5.85 \\
\hline & \multicolumn{11}{|c|}{ Cumulative Attributes } \\
\hline & \begin{tabular}{|l|}
$\mathrm{P}+\mathrm{L}+\mathrm{U}$ \\
\end{tabular} & -0.27 & $0.47^{\star}$ & $0.48^{\star}$ & -0.07 & $0.47^{\star}$ & $0.51^{\star \star}$ & $0.58^{\star \star}$ & $0.49^{\star}$ & $0.46^{\star}$ & $0.57^{\star \star}$ \\
\hline & $\begin{array}{l}\text { Adjusted } \\
\mathrm{R}^{2}\end{array}$ & 0.04 & $0.19^{\star}$ & $0.19^{\star}$ & -0.04 & $0.18^{*}$ & $0.23^{\star \star}$ & $0.34^{\star \star}$ & $0.24^{*}$ & $0.18^{*}$ & $0.33^{\star \star}$ \\
\hline \multirow{8}{*}{ 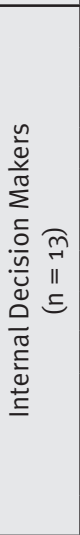 } & Power & -0.36 & 0.17 & 0.33 & -0.44 & 0.65 & -0.07 & -0.19 & 0.10 & $0.64^{*}$ & 0.38 \\
\hline & Legitimacy & 0.08 & -0.03 & -0.17 & -0.23 & 0.21 & -0.14 & -0.19 & -0.18 & -0.08 & -0.02 \\
\hline & Urgency & 0.69 & $0.69^{\star}$ & $0.70^{*}$ & $1.21^{\star \star}$ & 0.02 & 0.75 & $1.08^{\star \star}$ & $0.76^{\star}$ & 0.38 & 0.46 \\
\hline & $\begin{array}{l}\text { Adjusted } \\
\mathrm{R}^{2} \\
\end{array}$ & 0.02 & $0.56^{\star}$ & $0.72^{\star \star}$ & $0.72^{\star \star}$ & 0.53 & 0.24 & $0.72^{\star \star}$ & $0.48^{\star}$ & $0.79^{\star \star}$ & $0.52^{*}$ \\
\hline & $\mathrm{F}$ & 1.08 & 5.97 & 11.51 & 11.19 & 5.44 & 2.24 & 11.19 & 4.24 & 15.98 & 5.40 \\
\hline & \multicolumn{11}{|c|}{ Cumulative Attributes } \\
\hline & $\mathrm{P}+\mathrm{L}+\mathrm{U}$ & 0.34 & $0.74^{\star \star}$ & $0.78^{\star \star}$ & 0.49 & $0.77^{\star \star}$ & 0.50 & $0.63^{*}$ & $0.62^{*}$ & $0.86^{\star \star}$ & $0.76^{\star \star}$ \\
\hline & \begin{tabular}{|l|} 
Adjusted \\
$\mathrm{R}^{2}$ \\
\end{tabular} & 0.04 & $0.51^{\star \star}$ & $0.57^{\star \star}$ & 0.17 & $0.55^{\star \star}$ & 0.17 & $0.34^{\star}$ & $0.32^{\star}$ & $0.71^{\star \star}$ & $0.54^{\star \star}$ \\
\hline
\end{tabular}

a Standardized coefficients are represented; ${ }^{* *} p<0.01 ;{ }^{*} p<0.05$. 
These results corroborate other studies in the literature, particularly Bravo (2004), by confirming that individual and cumulative attributes are also related to the salience of some of the stakeholder groups defined. Parent and Deephouse (2007) and Agle et al. (1999) also found these same attributes positively correlate with salience.

According to Harrison et al. (2010), power is the first criterion to be taken into account in the process of influencing the organization's decisions. However, the results set out above show a curious aspect with regard to this attribute, since internal and external decision makers exhibit the same perception relating to not considering the stakeholder top management as being significant to the power of strategic decision making in the club. These results point in the opposite direction to that of Anagnostopoulos (2011), who indicated in their study that, by applying the model of Mitchell et al. (1997), in the professional football context in order to identify key stakeholders, the decisions of the directors are determinant for the degree of interconnection and involvement between other groups of stakeholders. Also, Walters (2011), with the objective of identifying the stakeholders involved in the decision to build a new football stadium, concluded that, although many have done so, only the top management of the club and the local government did more actively. In the same sense, Thiel and Mayer (2009) state that it is the board that defines strategies and adapt them to maximize resources from stakeholders. The results indicate that, in the perception of external stakeholders, the attribute of power is mainly attributed to the stakeholders included in the Operations Management group, which includes coaches, players and technical directors, as well as Government and Federations that are part of the group of Regulatory Bodies. This result is explained because these two stakeholders are the main subsidiary of sporting activities (Wicker \& Breuer, 2013). Note that in terms of the organizational hierarchy, these results point to a weak intervention for the group of Top management in the process of strategic decision making evidencing the need to exist a more active role in this group of stakeholders to improve the coordination between the general guidelines given by the Government and Federations and stakeholders who have the mission to implement them.

Despite being a professional club, we should note the emphasis given by the group of internal decision makers to the stakeholder Local Community, a kind of relationship that begins to be recommended by other investigations in the context of football clubs (Breitbarth \& Harris, 2008; Zagnoli \& Radicchi, 2010; Walters, 2011).
The results of this study demonstrate that the legitimacy attribute does not correlate with salience in individual attributes and remaining the case for both internal and external decision makers. We may therefore conclude that legitimacy is a less relevant individual attribute for the decision-making group in this club concerning the establishment of priorities requested by stakeholders.

The fact of not having been given the power to the group of stakeholders Top Management and that the legitimacy of any of the ten stakeholder groups included in the study has not been recognized raises doubt on the model proposed by Mitchell et al. (1997) particularly when applied to the context of sports organizations, pointing to a positive correlation between the three attributes $(P+L+U)$ and salience, as concluded Parent and Deephouse (2007).

On the other hand, these authors also argued that the attribute of power can assume greater prominence followed by urgency and legitimacy. These results highlight the need for organizations, in general, and sports clubs, in particular, to define those who actually have the legitimacy to intervene in the strategic decision process and the power to do so. This clarification also allows us to identify more clearly what are the primary and secondary stakeholders (Clarkson, 1995; Zagnoli \& Radicchi, 2010) and, for that reason, they are crucial to the survival of the club.

\section{Typology and prioritization of club stakeholders}

To prioritize and classify stakeholder groups, the Pearson test analyzed the correlations relating to the three attributes, with salience for both stakeholder groups (Table 3).

Correspondingly, for external decision makers, salience is observed as significantly correlated with the stakeholder groups of: top management ( $P$ and $U \mathrm{p}<0$.01); member associations ( $P p<0.01$ and $U p<0.05)$; competitors and the media ( $P p$ $<0.05, L p<0.01$ and $U p<0.01$ ); partners ( $P$ and $L p<0.01$ and $U$ $\mathrm{p}<0.05)$; and regulatory bodies ( $P$ and $L p<0.01)$ and $U p<0.01$ ). As for the operations management and sponsor groups, they do not return any correlation with any of the three attributes.

Concerning internal decision makers, the results obtained indicate that salience significantly correlates with the following groups: top management $(P, L$ and $U p<0.01)$; operations management and member associations ( $P p<0.05$ and $U$ $p<0.01)$; sponsors $(U p<0.01)$; competitors $(P p<0.01$ and $U p<$ $0.05)$; the media ( $P p<0.05$ and $U p<0.01)$; partners $(U p<0.05)$; regulatory bodies and the local community $(P p<0.01$ and $U p<$ o.01); and suppliers ( $\mathrm{u}<0.01)$. 
TABLE 3. Means, standard deviations and correlations of stakeholder attributes and stakeholder salience, in external decision makers

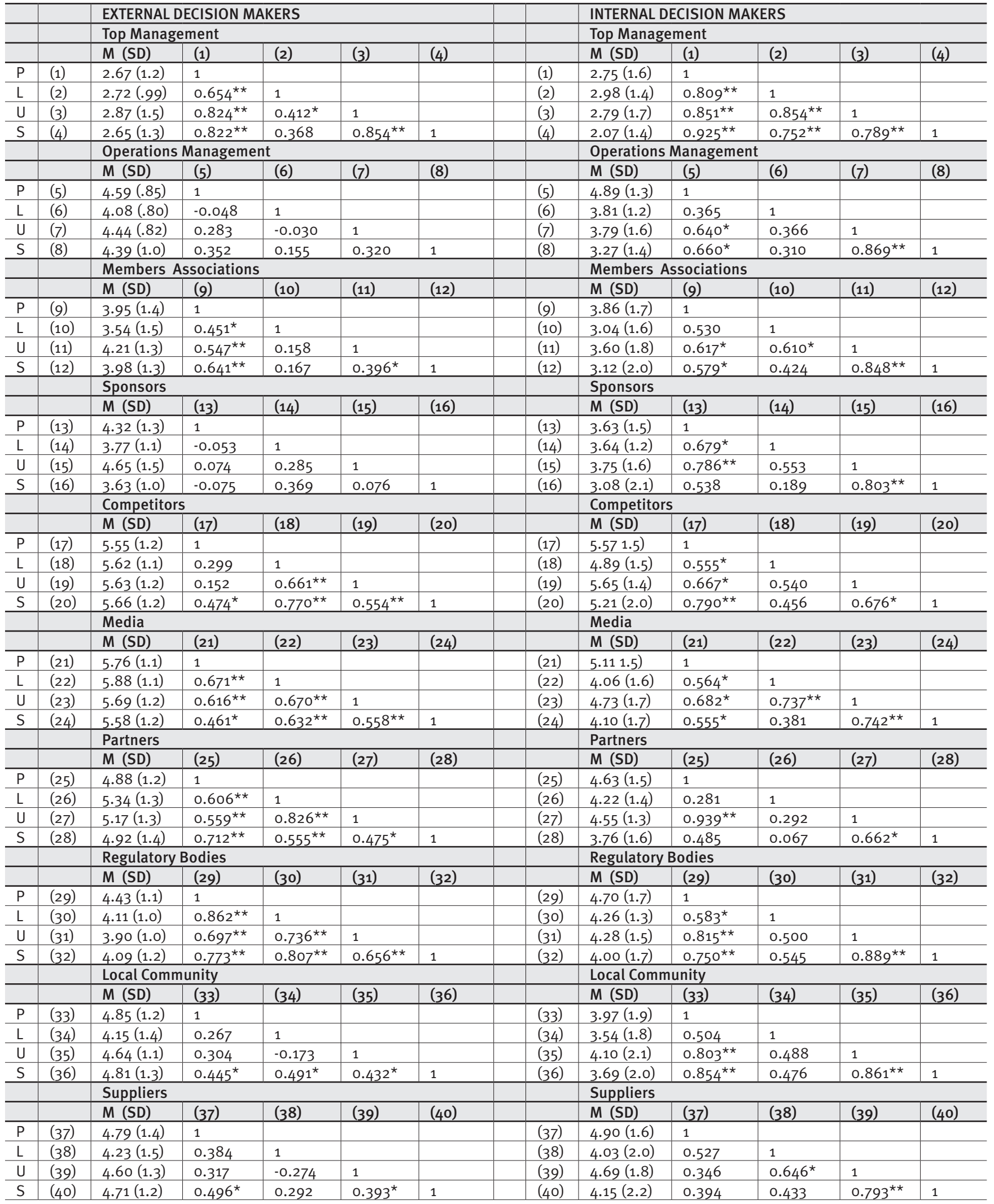

Statistics $=$ Pearson Correlation **. Correlation is significant at the 0.01 level (2-tailed). *. Correlation is significant at the 0.05 level (2-tailed). 
The means reveal the three stakeholder groups with the most emphatic importance, and simultaneously for power, legitimacy, urgency and salience, in the perception of external decision makers, are: top management $(P=2.67, L=2.72, U=2.87$ and $\mathrm{S}=2.65)$; member associations $(\mathrm{P}=3.95, \mathrm{~L}=3.54, \mathrm{U}=4.21$ and $\mathrm{S}=3.98)$; and sponsors $(\mathrm{P}=4.32, \mathrm{~L}=3.77, \mathrm{U}=4.65$ and $\mathrm{S}=$ 3.63). Concerning internal decision maker perceptions, the same stakeholder groups were found to have the most emphatic importance, but with different mean values for the respective different variables: top management $(\mathrm{P}=2.75, \mathrm{~L}=2.98, \mathrm{U}=2.79$ and $\mathrm{S}=$ 2.07); member associations ( $P=3.86, L=3.04, U=3.60$ and $S$ 3.12); and sponsors $(P=3.63, L=3.64, U=3.75$ and $S=3.08)$.

These results indicate unanimous perception of these two stakeholder groups suggesting that managers of sports clubs should take into account the inclusion and involvement of these stakeholders in strategic decision making. On the other hand, the stakeholder theory helps us understand concretely who should be given priority in formulating the strategy and how we can establish relationships between different groups of stakeholders (Sotiriadou, 2009). It is still interesting that both analyzed groups consider that the partners should also be an integral part of the substantive decisions of the club, no longer seen as merely a source of income of such organizations (Thiel \& Mayer, 2009). Although the sponsors have been considered relevant in the strategic decision making of clubs, we alert to the fact that their intervention at this level deserves some caution, since their interests, in most cases financial, should not overlap the mission of these types of clubs.

As for the top management group, this result probably stems from their direct linkage to club management. This evidence was corroborated by the statements recorded in response to the open question on the questionnaire: Of the stakeholders presented, indicate which ones you consider most important for defining club strategy, and give a short justification for your choice for each stakeholder you indicated, as both internal and external decision makers consider this stakeholder group serves to "lead, supervise and orient the club". As for the member association, it is the opinion of internal decision makers that this stakeholder group, "serves to support/reject the board's decisions" and for external decision makers "they are the critical mass of the club", or even as stated by the president of the Board "they own the club". Regarding sponsors, they are seen by both internal and external decision makers as "those who support the club financially". An important aspect to note is the fact that the local community group stands out with power, legitimacy and salience only for internal decision makers.

In terms of the least valued stakeholders for both types of decision-makers (Table 3), we find three identifiable groups: competitors and the media (in the perception of external decision makers) with means in the three attributes varying from 5.55 to 5.66 and from 5.58 to 5.88 , respectively; and competitors (in the perception of internal decision makers), varying between 4.89 and 5.65. These results are expected, since usually there is not usual the involvement of these two types of stakeholders in strategic decisions club. However, there are no longer two stakeholders is important to monitor regularly in order to assess whether the strategic way the club is adopting is adjusted to the challenges posed both by the competitive level of other clubs, or by information contained in the media.

Analysis of the correlations between the three attributes discussed above now underpins our classification (Mitchell et al., 1997) of the different stakeholder groups according to the perceptions of the internal and external decision makers. In the case of external decision makers, three types of stakeholders were identified. A first type includes the groups of top management, member associations and suppliers and classified as dangerous stakeholders, with top management standing out as the most dangerous group $(P=.822$ and $U=.854)$. This fact may mean all these stakeholders may potentially harm the organization through deploying their power.

A second group, designated as definitive stakeholders, includes the groups of competitors, the media, partners, regulatory bodies and the local community, where regulatory bodies stands out as the most definitive, and reporting the highest values $(P=0.713, L=0.656$ and $U=0.807)$. In the eyes of external decision makers, these stakeholder types, and particularly the group of regulatory bodies, are those deemed worthy of receiving the greatest attention from the organization, with priority awarded to their requests and problems. On the other hand Anagnostopoulos (2011) obtained two groups of definitive stakeholders, the employees and the Supporters' clubs.

The third and final stakeholder type identified contains the operations management and sponsor groups, classified as belonging to the non-stakeholder type, because not currently includes any attribute. However, this does not mean they will not attain importance in organizational decision making over the medium/long term.

Concerning internal decision makers, we also identified three stakeholder types. Only the top management group emerges in the first stakeholder type, and is classified as a definitive stakeholder according to Bravo (2004), though parents have also been identified as a definitive stakeholder, as the study was applied to a school athletic department. Therefore, the organization pays this type of stakeholder total and priority attention as it is the most salient. However, such recognition is not attributed by external decision makers (who classified them 
as dangerous). Operations management, member associations, competitors, the media, regulatory bodies and the local community form the second type of stakeholder, classified as dangerous. However, the regulatory bodies group stands out as the most dangerous $(P=0.750$ and $U=0.889$ ), followed up by the local community group $(P=0.854$ and $U=0.861)$. In the third group, we find the groups of sponsors, partners and suppliers, which were classified as demanding stakeholders, with sponsors standing out as the most demanding group $(U=0.803)$. These, therefore, whilst making themselves most heard, in fact, do not get much attention from decision makers.

It is worth highlighting that the member associations were the only stakeholder group classified as dangerous by both external and internal decision makers. This study also found these relationships, as external decision makers consider the definitive stakeholders as those who have an external connection with the club. As for internal decision makers, they attribute priority to those connected with daily club management, particularly the top management. Therefore, the results show that there are significant differences in the two perceptions of club decision makers. These differences may be explained by the fact that respondents carry out functions directly in the organization, which to a certain extent shape stakeholder attitudes towards prioritization and perceptions (Freeman, 1984).

\section{CONCLUSION}

Stakeholders are actors performing strategic roles to organizations. However, we know little about the relationships between sports management organizations and stakeholders. This study attempts to identify and analyze external and internal stakeholders' perceptions on strategic decision making and to evaluate the impact of the relationships among the attributes of power, legitimacy and urgency on the salience of these stakeholders.

Three most valued stakeholder groups were highlighted in the strategic decision-making process (top management, member associations and sponsors), suggesting that they are primary stakeholders who should be given special attention. This study shows that external and internal stakeholders do not consider the stakeholder top management as having power in strategic decision making and legitimacy was the attribute that with the least influence on stakeholder salience. This highlights the football clubs' need to define who has the legitimacy to get involved in the strategic decision process and the power to do so.

Results show significant differences between external and internal decision makers in stakeholder's classification, except for the member association, which is classified equal- ly from both stakeholder groups as dangerous. Furthermore, we find the group deemed to warrant the most attention is top management, identified as the most salient group, justifying the theory that internal decision makers tend to attribute greatest importance to the organization's internal stakeholders (Parent \& Deephouse, 2007). However, other groups were identified as more dangerous, such as the regulatory bodies and the local community, and thus able to harm the organization through their powers. Such perceptions may arise because the regulatory bodies, including the Government and the Federation are crucial to the club activities, thus generating its great power and urgency. The local community might also apply its powers to harm the club and is thus worthy of great importance during the course of decision-making processes.

Despite the incidence of the aforementioned stakeholder, others should not be ignored by the organization, such as sponsors, which may nevertheless have some weight in strategic decision making (Parent \& Séguin, 2007; Sotiriadou, 2009; Ferkins \& Shilbury, 2010).

In this context, considering the co-existence of all the stakeholders involved and ensuring transparent communication between them does not only encourage increased efficiency but also proves a driver of motivation and confidence among and for all stakeholders, and whether contracted or volunteers (Parent \& Séguin, 2007; Harrison et al., 2010; Walters \& Tacon, 2010).

Therefore, decision makers at any organization, but at this club in particular, should constantly strive to identify which stakeholders belong to the organization and which merit its greatest attention. Furthermore, we should emphasize that intra- and extra-organizational dynamics may take on new configurations reflected in the prioritization and relevance of stakeholders over the course of time.

We therefore recommend that there be a pro-active approach to organizational management so as to pre-empt and coordinate the responses and requests of the various stakeholders. This attitude enables the maximization and maintenance of a favorable position in relation to all organizational interests in strategic decision making (Friedman et al., 2004). Thus, successful organizational management depends on the correct identification of stakeholders and subsequent assessment of their actual relevance in order to highlight who deserves priority and how (Neville et al., 2011).

A generalization of these results to other sports organizations should be carried out with due care and concern since each case is different and should be studied as such. Another aspect to highlight concerns the limited number of questionnaires obtained, which, to a certain extent, may mean less robust data. Therefore, future research should focus on this model 
of analysis by broadening it to other sports organizations. Development of this type of study from a longitudinal perspective is also suggested in order to accompany and understand the underlying reasons for decision maker perceptions about the prioritization of stakeholder salience attributes. It will prove interesting to analyze just what effect management style has on organization performance.

\section{REFERENCES}

Aaltonen, K., Jaakko, K., \& Tuomas, O. (2008). Stakeholder salience in global projects. International Journal of Project Management, 26(5), 509-516.

Agle, B., Mitchell, R., \& Sonnenfeld, J. (1999). Who matters to CEOs? An investigation of stakeholder attributes and salience, corporate performance, and CEO values. Academy of Management Journal, 42(5), 507-525.

Anagnostopoulos, C. (2011). Stakeholder management in Greek professional football: identification and salience. Soccer \& Society, 12(2), 249-264.

Bravo, G. A. (2004). An Investigation of stakeholder influence and institutional pressures on budget strategies of high school athletic departments. 2004. 223 p. PhD thesis, The Ohio State University, Ohio.

Breitbarth, T. \& Harris, P. (2008). The role of corporate social responsibility in the football business: Towards the development of a conceptual model. European Sport Management Quarterly, 8(2), 179-206.

Clarkson, M. (1995). A stakeholder framework for analyzing and evaluating corporate social performance. Academy of management review, 20(1), 92-117.

Donaldson, T. \& Preston, L. E. (1995). The stakeholder theory of the corporation: concepts, evidence, and implications. The Academy of Management Review, 20(1), 65-91.

Driscoll, C. \& Starik, M. (2004). The primordial stakeholder: advancing the conceptual consideration of stakeholder status for the natural environment. Journal of Business Ethics, 49(1), 55-73.

Eesley, C. \& Lenox, M. J. (2006). Firm responses to secondary stakeholder action. Strategic Management Journal, 27(8), 765-781.

Esteve, M., Di Lorenzo, F., Inglés, E., \& Puig, N. (2011). Empirical evidence of stakeholder management in sports clubs: the impact of the board of directors. European Sport Management Quarterly, 11(4), 423-440.

Ferkins, L. \& Shilbury, D. (2010). Developing board strategic capability in sport organisations: the national-regional governing relationship. Sport Management Review, 13(3), 235-254.

Field, A. (2005). Discovering statistics using SPSS. 2nd ed. London: Sage Publications. $779 \mathrm{p}$.

Freeman, R. (1984). Strategic management: A stakeholder approach. Toronto: Pitman Publishing. $152 \mathrm{p}$.

Freeman, R. \& Reed, D. (1983). Stockholders and stakeholders: a new perspective on corporate governance. California Management Review, 25(3), 88-106.
Friedman, M., Parent, M., \& Mason, D. (2004). Building a framework for issues management in sport through stakeholder theory. European Sport Management Quarterly, 4(3), 170-190.

Harrison, J. S., Bosse, D. A., \& Phillips, R. A. (2010). Managing for stakeholders, stakeholder utility functions, and competitive advantage. Strategic Management Journal, 31(1), 58-74.

Holt, M. (2007). The ownership and control of elite club competition in European football. Soccer \& Society, 8(1), 50-67.

Mainardes, E. W., Alves, H., \& Raposo, M. (2011). Stakeholder theory: issues to resolve. Management Decision, 49(2), 226-252.

Mainardes, E. W., Alves, H., \& Raposo, M. (2012). A model for stakeholder classification and stakeholder relationships. Management Decision, 50(10), 1861-1879.

McDonald, H. \& Sherry, E. (2010). Evaluating sport board club performance: a customer perspective. Journal of Sport Management, 24(5), 524-543.

Michie, J. \& Oughton, C. (2005). The corporate governance of professional football clubs in England. Corporate Governance: An International Review, 13(4), 517-531.

Mitchell, R., Agle, B., \& Wood, D. (1997). Toward a theory of stakeholder identification and salience: defining the principle of who and what really counts. Academy of management review, 22(4), 853-886.

Neville, B. A., Bell, S. J., \& Whitwell, G. J. (2011). Stakeholder salience revisited: refining, redefining, and refueling an underdeveloped conceptual tool. Journal of Business Ethics, 102(3), 357-378.

Nguyen, S. N. \& Menzies, J. (2010). Event effectiveness: analysing the perceptions of key stakeholders of the Lexmark Indy 300/Champ Car Event, Gold Coast. International journal of sport management and marketing, 8(1-2), 106-130.

Olander, S. (2007). Stakeholder impact analysis in construction project management. Construction Management and Economics, 25(3), 277-287.

Parent, M. M. \& Deephouse, D. L. (2007). A case study of stakeholder identification and prioritization by managers. Journal of Business Ethics, 75(1), 1-23.

Parent, M. M., Rouillard, C., \& Leopkey, B. (2011). Issues and strategies pertaining to the Canadian governments' coordination efforts in relation to the 2010 Olympic Games. European Sport Management Quarterly, 11(4), 337-369.

Parent, M. M. \& Séguin, B. (2007). Factors that led to the drowning of a world championship organizing committee: a stakeholder approach. European Sport Management Quarterly, 7(2), 187-212.

Peachey, W. \& Bruening, J. (2011). An examination of environmental forces driving change and stakeholder responses in a Football Championship Subdivision athletic department. Sport Management Review, 14(2), 202-219.

Russo, A. \& Vito, G. (2011). Introduction. European Sport Management Quarterly, 11(4), 327-335.

Sallent, O., Palau, R., \& Guia, J. (2011). Exploring the legacy of sport events on sport tourism networks. European Sport Management Quarterly, 11(4), 397-421.

Samaras, S. (2010). The measurement of stakeholder salience: a strategy for the exploration of stakeholder theories. International Journal of Data Analysis Techniques and Strategies, 2(3), 285-306.

Shropshire, C. \& Hillman, A. J. (2007). A longitudinal study of significant change in stakeholder management. Business \& society, 46(1), 63-87. 
Sotiriadou, K. (2009). The Australian sport system and its stakeholders: development of cooperative relationships. Sport in Society, 12(7), $842-860$.

Stevens, A., \& Watkins-Mathys, L. (2006). The FA's role in developing five-a-side football: strategic alliances with stakeholders. Managing Leisure, 11(3), 186-202.

Thiel, A. \& Mayer, J. (2009). Characteristics of voluntary sports clubs management: a sociological perspective. European Sport Management Quarterly, 9(1), 81-98.

Walters, G. (2011). The implementation of a stakeholder management strategy during stadium development: a case study of Arsenal Football Club and the Emirates Stadium. Managing Leisure, 16(1), 49-64.
Walters, G. \& Tacon, R. (2010). Corporate social responsibility in sport: stakeholder management in the UK Football Industry. Journal of Management \& Organization, 16(4), 566-586.

Wicker, P. \& Breuer, C. (2013). Understanding the importance of organizational resources to explain organizational problems: evidence from nonprofit sport clubs in Germany. VOLUNTAS: International Journal of Voluntary and Nonprofit Organizations, 24(2), 461-484.

Xue, H. \& Mason, D. S. (2011). The changing stakeholder map of formula one grand prix in Shanghai. European Sport Management Quarterly, 11(4), 371-395.

Zagnoli, P. \& Radicchi, E. (2010). The football-fan community as a determinant stakeholder in value co-creation. Sport in Society, 13(10), $1532-1551$. 